\title{
Linguistic and Sociocultural Features of The American Comic Book Movies
}

\author{
Olga Kuznetsova*, Nadezhda Karacheva, Ivan Solsoev, and Mikhail Kuznetsov \\ Foreign Languages Department, Irkutsk State University, Irkutsk, Russia
}

\begin{abstract}
The article analyzes the linguistic and sociocultural features of the American comic book movies. The purpose of this article is to identify the distinctive features of American super hero movies, as well as to analyze the changes that have occurred in the images of the main characters and their socio-cultural preconditions.
\end{abstract}

\section{Introduction}

Nowadays comics are constantly present in our lives - in advertising, newspapers magazines and on the Internet. Comic books are a developed industry, especially in the United States of America. It seems relevant to consider comics precisely as a linguistic and sociocultural phenomenon in order to follow changes in the culture and traditional values of the American people. «Scholars have opened up many new avenues of exploration as they begin tracing ways in which modern culture engages with the world» [1]. In addition, modern American mass culture is mainly aimed at promoting the American way of life and Western values in other countries, which also makes the study of various sociocultural phenomena of this country relevant. «There is a lack of works on the American comic's history. Meanwhile, the developing industry of painted stories provides the need for the information about the history of the industry to a broad audience, and it would be foolish to deny it» [2].

The purpose of this article is to identify the distinctive features of American super hero movies, as well as to analyze the changes that have occurred in the images of the main characters and their socio-cultural preconditions.

Results and discussion.

Comics - a kind of «commercial art», a paradoxical phenomenon of the post-cultural era. Comics first appeared in the US in the late 19th century, and were presented in the form of funny pictures series (the modernized form of the alphabet) aimed at teaching children to read and write. «By the term «comics» we mean what the Americans call a «comic book», that is a kind of separated comics magazine. The birth of this primordially American form did not happen immediately:

- In 1929, the publishing house «Dell Publishing» released a sixteen-page newspaper comic book called «The Funnies».
- In 1933, «Eastern Color Printing» published a similar newspaper (but with fewer pages) «Funnies on Parade».

- In the same year, «Famous Funnies: A Carnival of Comics» was published by «Eastern Color» in collaboration with «Dell». This publication, intended for sale in the network of stores «Woolworth», opened the story of the American comics. The price was not indicated, and the magazine was sold for a dime a copy, which became the standard price for comics for years to come. In 1934, the edition became periodic, having generated a whole wave of imitators. In 1938, the magazine «Action Comics \# 1» appeared, presenting the world with a new hero - Superman, and with it a new genre - super hero comics» [2].

In «The Secret History of Comics» [2] the author gives the following periodization of the history of American comics:

\begin{tabular}{|c|c|}
\hline $\begin{array}{l}\text { The Golden } \\
\text { Age } \\
(1938-1950)\end{array}$ & $\begin{array}{l}\text { Magazines were sold in huge } \\
\text { editions. The most popular form of } \\
\text { entertainment of Americans before } \\
\text { this period was reading pulp-fiction } \\
\text { (cheap paperback books printed on } \\
\text { low-quality paper), by the end of the } \\
\text { decade, the publishers of the ««pulp»" } \\
\text { massively mastered the publication of } \\
\text { comic books. National Publications } \\
\text { (DC Comics now), which launched a } \\
\text { new cultural trend with the release of } \\
\text { Action Comics, created a series for } \\
\text { many other superheroes. Batman, } \\
\text { Wonder Woman, Green Lantern, } \\
\text { Flash and Sand Man crushed the } \\
\text { gangsters on the colored pages of } \\
\text { their editions. The main competitor } \\
\text { was the publishing house Fawcett, } \\
\text { which released comics about Billy } \\
\text { Batson adventures, a boy capable of } \\
\text { turning into the mighty Captain }\end{array}$ \\
\hline
\end{tabular}

* Corresponding author: kuznetsova1@ mail.ru 


\begin{tabular}{|c|c|}
\hline & $\begin{array}{l}\text { Marvel with the magic word } \\
\text { «Shazam!». The same period includes } \\
\text { the first steps of the Marvel company } \\
\text { (first called Timely), they, among } \\
\text { other things, published a super- } \\
\text { popular series about the adventures of } \\
\text { Captain America. } \\
\text { The peak of the superheroes } \\
\text { popularity was achieved during the } \\
\text { Second World War. By the end of the } \\
\text { 1940s, new genres gradually took up } \\
\text { place: crime (stories about gangsters), } \\
\text { horror (horror comics, either } \\
\text { exploiting popular cinematographic } \\
\text { and literary images, or printing } \\
\text { original stories with O. Henry finals), } \\
\text { war comics (about military } \\
\text { adventures), romance comic genre } \\
\text { (sentimental stories). Superheroes } \\
\text { overtook the «overproduction crisis»: } \\
\text { huge quantities with low quality. } \\
\text { Eventually, by 1951, most of the } \\
\text { superhero series had been closed or } \\
\text { redone to meet the new genre } \\
\text { formats. }\end{array}$ \\
\hline $\begin{array}{l}\text { The Comic- } \\
\text { Code Century } \\
(1950-1956)\end{array}$ & $\begin{array}{l}\text { This period is sometimes } \\
\text { considered a part of the Golden Age, } \\
\text { and sometimes is called the Atomic } \\
\text { Age (the world situation of the fifties, } \\
\text { of course, affected comics as well). } \\
\text { Meanwhile, these six years are } \\
\text { strikingly different from the previous } \\
\text { era, and the theme of peaceful atom } \\
\text { and nuclear war was one of the } \\
\text { features of that time. } \\
\text { The period of decreasing interest } \\
\text { in superheroes coincided with the } \\
\text { anti-comic hysteria that spread over } \\
\text { the US in the fifties. Extensive } \\
\text { harassment, deployed in the media, } \\
\text { reached the Congress, and as a result, } \\
\text { the so-called Comic Code was } \\
\text { established. Comics that did not fit } \\
\text { the accepted standards simply did not } \\
\text { appear on the shelves and widespread } \\
\text { distribution on newsstands, which in } \\
\text { those days, when there were no } \\
\text { specialized comic bookstores, meant } \\
\text { 80\% of the success. "Thanks to } \\
\text { Comic-Code crime and horror genres } \\
\text { virtually disappeared from the market } \\
\text { until the end of the sixties. Instead of } \\
\text { classic horror came a new genre - } \\
\text { monster comics, such as «King } \\
\text { Kong» and «Godzilla». } \\
\text { Jack Kirby created the super- } \\
\text { popular Captain America (and in fact } \\
\text { laid the foundation for military comic } \\
\text { books), and in so doing developed } \\
\text { another genre. In the fifties, Kirby } \\
\text { worked in a variety of genres, but the }\end{array}$ \\
\hline
\end{tabular}

\begin{tabular}{|c|c|}
\hline & $\begin{array}{l}\text { turning point was his comic } \\
\text { «Challengers of the Unknown», } \\
\text { which generated a whole wave of } \\
\text { similar comic books. In these stories, } \\
\text { ordinary people (brilliant scientists, } \\
\text { of course, handsome athletes, etc.) } \\
\text { faced sci-fi threats such as alien } \\
\text { invasions or sinister travelers in time. } \\
\text { In the same period, the first union } \\
\text { of comic books and television took } \\
\text { place - the series «Adventures of } \\
\text { Superman» was so popular that one } \\
\text { of the minor characters, the young } \\
\text { reporter Jimmy Olsen, received his } \\
\text { own comic book series. } \\
\text { The era ended when DC Comics } \\
\text { returned to the pages of their } \\
\text { magazines Flash - the hero of the } \\
\text { Golden Age, but in a slightly } \\
\text { modified form: another alter ego, } \\
\text { another suit, but the same abilities. } \\
\text { While the «old» Flash mostly fought } \\
\text { with gangsters, the new one dealt } \\
\text { with fantastic villains. }\end{array}$ \\
\hline $\begin{array}{l}\text { The Silver Age } \\
(1956-1971)\end{array}$ & $\begin{array}{l}\text { Thanks to the success of Flash, } \\
\text { DC again took up superheroes. Their } \\
\text { colleagues from Timely-Atlas } \\
\text { became Marvel: in ten years they } \\
\text { created a galaxy of the most popular } \\
\text { heroes - the Fantastic Four, Spider- } \\
\text { Man, the Avengers, X-Men, } \\
\text { Daredevil and many others. } \\
\text { DC again occupied the screen in } \\
\text { the late sixties with the series } \\
\text { «Batman», which became popular } \\
\text { even in Japan, where it was based on } \\
\text { manga. Marvel launches a series of } \\
\text { animated series, performed in the } \\
\text { advanced (and extremely cheap) } \\
\text { «motion comics» style. } \\
\text { Collecting comics came with } \\
\text { collecting coins and stamps. From } \\
\text { this time, this was not a hobby for } \\
\text { children any more, but a serious } \\
\text { business: catalogs were produced, } \\
\text { intermediary companies started } \\
\text { looking for old circulations, and } \\
\text { prices were rising. If at the beginning } \\
\text { of the Silver Age the target audience } \\
\text { of comics were twelve-year-olds, by } \\
\text { the beginning of the seventies } \\
\text { publishers began to focus on students. } \\
\text { Feedback between editors and readers } \\
\text { occurred through the letters and } \\
\text { editorial appeals, the creators were } \\
\text { not just a couple of lines in the corner } \\
\text { of the title page, but recognizable } \\
\text { persons ready to make contact. By the } \\
\text { end of the sixties, the first comic- } \\
\text { festivals were arranged and gaining } \\
\text { strength. }\end{array}$ \\
\hline
\end{tabular}




\begin{tabular}{|c|c|}
\hline & $\begin{array}{l}\text { The comic book finally took a } \\
\text { modern look: one or two stories on } \\
\text { the magazine, the cover anticipates } \\
\text { the coming story's conflicts. Fiction } \\
\text { became the main genre, especially in } \\
\text { superhero form. }\end{array}$ \\
\hline $\begin{array}{l}\text { The Bronze } \\
\text { Age } \\
(1971-1986)\end{array}$ & $\begin{array}{l}\text { A new era began with the return } \\
\text { of Jack Kirby from Marvel company } \\
\text { to DC Comics, where he created an } \\
\text { ambitious (but unimportantly } \\
\text { accepted by readers) project «Fourth } \\
\text { World», developing his ideas about } \\
\text { the deities of other worlds, laid down } \\
\text { in the annex to the story of the Torah, } \\
\text { «Stories of Asgard», which he } \\
\text { painted for Marvel. } \\
\text { A little later DC planned «DC } \\
\text { Explosion», the release of a huge } \\
\text { number of new series, which would } \\
\text { turn into the biggest crisis in the } \\
\text { history of the publishing house. } \\
\text { Marvel successfully overcame the } \\
\text { same crisis by obtaining a license to } \\
\text { release comic books based on «Star } \\
\text { Wars» and expanding the market } \\
\text { outside of America by opening a } \\
\text { branch of Marvel UK. Science fiction } \\
\text { in comics acquired features of } \\
\text { psychedelic culture, and fantasy } \\
\text { (thanks to the series about Conan } \\
\text { from Marvel and about Varlord at } \\
\text { DC) becaming one of the main comic } \\
\text { genres of the seventies. } \\
\text { Jack Kirby returned to Marvel, } \\
\text { becoming available to a wide range of } \\
\text { American readers with the release of } \\
\text { Heavy Metal magazine. } \\
\text { characters, and continued the line of } \\
\text { «Fourth World» in the comic book } \\
\text { «The Eternal». Then, depressed by } \\
\text { low sales, he went into the world of } \\
\text { animation, where he once started his } \\
\text { career, and occasionally drew new } \\
\text { comics. } \\
\text { Television and cinema are } \\
\text { increasingly turning to comics and } \\
\text { very successfully from both positions, } \\
\text { as art and as business. }\end{array}$ \\
\hline $\begin{array}{l}\text { The Iron Age / } \\
\text { The Dark Age, } \\
(1986-1992)\end{array}$ & $\begin{array}{l}\text { «The Dark Age» is the time of an } \\
\text { unprecedented expansion of English } \\
\text { authors. By analogy with rock music } \\
\text { of the sixties, it was called the } \\
\text { «British Invasion». A new format for } \\
\text { publishing comics appeared - the } \\
\text { "graphic novel», it allowed comics to } \\
\text { get on the shelves of bookstores. }\end{array}$ \\
\hline
\end{tabular}

\begin{tabular}{|c|c|}
\hline & $\begin{array}{l}\text { There were new publishers, and } \\
\text { underground comics started being } \\
\text { able to compete with the mainstream. } \\
\text { In addition, manga in America for the } \\
\text { first time appeared. With increased } \\
\text { interest in the old comic books, the } \\
\text { new generation was acquainted with } \\
\text { the works of Will Eisner, old horror } \\
\text { comics and «forgotten» superheroes. } \\
\text { The authors of the comics now } \\
\text { took the rock star model: they } \\
\text { performed at festivals, went on tours } \\
\text { around the world, and got fabulous } \\
\text { money. Religious status was found in } \\
\text { the works of Frank Miller, Alan } \\
\text { Moore, Grant Morrison and many } \\
\text { others. The names of the creators on } \\
\text { covers became more important than } \\
\text { the names of the characters, an } \\
\text { unthinkable story in fact for the } \\
\text { previous eras of comic magazines. } \\
\text { Subjects of comics became gloomier } \\
\text { and «more mature», which, in the } \\
\text { end, would give birth to the next era. }\end{array}$ \\
\hline $\begin{array}{l}\text { Baroque / The } \\
\text { Image Age } \\
(1992-1998)\end{array}$ & $\begin{array}{l}\text { This era was created by three } \\
\text { Marvel people (Todd MacFarlane, } \\
\text { Rob Liefeld, Jim Lee) became one of } \\
\text { the industry leaders. There was a } \\
\text { clear primacy of the visual side over } \\
\text { the storyline. The style of artist-stars } \\
\text { became a pass to the world of big } \\
\text { comic books; as a result, by the end } \\
\text { of the era, even one of its lawmakers, } \\
\text { Rob Layfeld, began to be perceived } \\
\text { as mediocrity. } \\
\text { In general, this period can be } \\
\text { characterized as decadent. After the } \\
\text { commercial success of the eighties, a } \\
\text { predictable crisis of overproduction } \\
\text { followed, leading to the closure of } \\
\text { many publishers. } \\
\text { The result was a change in the } \\
\text { standards of comic issues: improving } \\
\text { the quality of printing and paper, the } \\
\text { dominance of computer coloring over } \\
\text { manual. Having positioned itself at } \\
\text { the beginning of the era as the main } \\
\text { engine of the production of new } \\
\text { journals, collecting did not justify its } \\
\text { expectations: the models that were } \\
\text { initially positioned as collectors' } \\
\text { items were produced in huge } \\
\text { numbers, which led to a predictable } \\
\text { fall in prices. } \\
\text { The author's branch of DC- } \\
\text { Vertigo became very popular. Marvel } \\
\text { experiments in this area failed (even a } \\
\text { whole series of magazines under the } \\
\text { patronage of the most popular writer } \\
\text { Clive Barker). }\end{array}$ \\
\hline The Dynamic & After the biggest crisis in the \\
\hline
\end{tabular}




\begin{tabular}{|c|c|}
\hline $\begin{array}{l}\text { Age } \\
(1998-2004)\end{array}$ & $\begin{array}{l}\text { history of Marvel, which led, in } \\
\text { particular, to the announcement of } \\
\text { bankruptcy, there was a reorientation } \\
\text { to a new teen market: the launch of } \\
\text { the Ultimate and Max series. DC was } \\
\text { not lagging behind in trying to reach } \\
\text { a new audience, and Image from } \\
\text { publishers of all kinds of kitsch are } \\
\text { turning into worthy competitors. The } \\
\text { underground scene went massively to } \\
\text { the web comics" format. } \\
\text { Cinema increasingly appealed to } \\
\text { comic books, and by the end of the } \\
\text { era, the cycle «comics-film-video } \\
\text { game-series of toys» finally born in } \\
\text { previous epochs was finally being } \\
\text { formed. Computer production } \\
\text { captured all stages of creating a } \\
\text { comic book, which in an } \\
\text { unprecedented way reduced the } \\
\text { prepress preparation. The industry } \\
\text { deftly tried to avoid crises of } \\
\text { overproduction. Another important } \\
\text { point is the popularization of reading } \\
\text { comics in electronic form. Also the } \\
\text { possibility of communication } \\
\text { between authors and readers in virtual } \\
\text { space gave dynamics to the process of } \\
\text { creating comic books - announcing } \\
\text { became a kind of game in «cheating } \\
\text { the deceiver», when the readers } \\
\text { together try to figure out what the } \\
\text { authors are going to do. The illusion } \\
\text { of involvement in the process, which } \\
\text { came from sports and television, is } \\
\text { becoming a characteristic feature of } \\
\text { the digital age industry. } \\
\text { By the end of the era there is a } \\
\text { tendency for «nostalgia», which was } \\
\text { born with a wave of reissues of the } \\
\text { eighties. Large publishers are } \\
\text { increasingly turning to their heritage, } \\
\text { publishing it in all possible forms and } \\
\text { formats. }\end{array}$ \\
\hline $\begin{array}{l}\text { The Modern } \\
\text { Age } \\
(2004-\ldots)\end{array}$ & $\begin{array}{l}\text { The modern era is the era of } \\
\text { major «events». DC, starting this } \\
\text { glorious tradition back in the eighties, } \\
\text { now and then resorted to «crises» } \\
\text { (stories related to many series } \\
\text { published by the publisher), and lead } \\
\text { to «reboots» of their fictional } \\
\text { universe, followed by a similar } \\
\text { scheme, they began to use in Marvel. } \\
\text { Electronic copies make comics } \\
\text { (especially comic books of the past) } \\
\text { available anywhere in the world. } \\
\text { Reissues of the classics of past } \\
\text { epochs acquire a cult character, as } \\
\text { well as the publication of «nostalgic» } \\
\text { comics about the characters of the } \\
\text { past. }\end{array}$ \\
\hline
\end{tabular}

\begin{tabular}{|l|l|}
\hline \multicolumn{1}{|c|}{ Films based on comic books } \\
are increasingly becoming incredibly \\
lucrative, and Marvel creates a \\
«movie universe»: every year films \\
come out connected, attracting more \\
and more readers to comics. Social \\
networks bring the publisher-reader \\
feedback virtually to the absolute. \\
There are large online libraries of \\
comics, and web journalism extends \\
the possibilities of exploring the \\
history of the phenomenon.
\end{tabular}

There are many definitions of comics, but all of them have in common that the comic is a series of images through which a story is told. According to most researchers, comics are the unity of narrative and visual action. Scott McCloud, the author of The Understanding comics, offers a concise definition; a «sequence of images» and more completely «adjacent pictures and other images in a semantic sequence» [3].

In linguistics the comic is a verb-iconic message, the textuality of which (and, more broadly, communicativity) is built on the constructive interaction of the three information series included in it: alphabetic text, graphics and paragraphs. Therefore, the question arises whether it is possible to consider this message as a text. According to E.V. Kozlov, «a sequence of signs of any order, united by goals, consisting in the most adequate expression of a semantic superstructure, can be understood as a text» [4]. E.E. Anisimova writes that in semiotics, iconic language is not fundamentally different from verbal language: "Any image created by a person is abstract, because it denotes the object's properties abstracted by man. In this function, the image does not differ from the word. Both the word and the image can express concepts of different levels of abstractness» [5]. Thus, the presence of non-verbal means in the comic shows itself, in other words, paralinguistic means allow us to attribute it to the texts, but it determines its belonging to a certain group of texts - creolized texts. «Comics feature two distinguishable semiotic tracks (images and words), because the images can represent multiple events going on at the same time, and because the composition and layout of the page guides the readers' gaze as it structures these simultaneous events into foreground and background» [6].

Comics, nevertheless, are more pictures, so it is important to simplify all the phrases, accompanying actions, expressions of emotions and vocabulary, which, in turn, lead to the creation of onomatopoeic units. Comics do not contain complex vocabulary, which requires such translational transformations, as, for example, semantic concretization. In other words, the language used by the heroes of the comics and the author's notes, in most cases, are intended for quick perception, which requires such expressions, words, and phrases of maximum simplicity. "The constraints of language are eluded at the expense of communicability» [7]. Thus, without detailed analysis, we can say that to recreate sounds and images, interjections and onomatopoetic lexical units are used. On the pages of 
American comics, they often use interjections and a set of random letters to represent sounds and create an appropriate situation for the comic book. Thus, the lexical units «FSSHAAAMM»; «THOK»; «WHACK» do not carry any specific meaning, the main function of these interjections is to create a «background» color and give the emotional brightness to the picture. «When the characters' speech is presented, especially in the direct mode, the reader will accept it without questioning whether or not the dialogue really took place in the story» [8]. Interjections, found on the pages of American comic books, are in many respects similar to those lexical units that can be chosen as direct equivalents in the Russian language. This can be explained by the fact that the structure of English and Russian as languages belonging to the Indo-European group is similar, therefore, in the translation process, and the search for an equivalent is not so complicated.

Accompanying each action of the hero with similar lexical units, the author of the comic gives an emotional color to the plot and «animates» the characters. American comics, whose idea, in most cases, is aimed at describing the adventures of superheroes, are characterized by the extremely rare use of interjections and any other lexical units to convey the state of the hero, his thoughts or the surrounding atmosphere. American comics, in general, contain many replicas, which can include not only the expressions used in everyday speech, but also complex utterances containing, for example, scientific terminology. In American comics, known throughout the world, heroes often use complex and lengthy phrases in their syntactic and grammatical structure of their sentences. In many respects, what the hero says depends on how he is represented in the comic book story, to what circle of people he belongs to, his age, life experience and the main occupation in life, therefore, often, the pages of American comic books can be found to be very «intricate» and it is difficult for foreigners to understand the vocabulary. There is also a place for onomatopoietic lexicon and interjections on the pages of American comics: ««BHOOOM»«, ««ZZZHHHRRRWWW»«, interjections perform an «audio» function, because the plot requires the creation of a certain atmosphere, which the receptor feels when reading a comic.

The 21 st century was marked by the emergence of a new concept of «movie universe». It has its own history, stunning imagination of infrastructure, objects, laws, phenomena and characters. Within the limits of a single movie, the chronological order of the release of films does not play a determining role. The so-called timeline can evolve regardless of the calendar schedule of the releases. It means that all the characters already exist in the given universe, even if they are not present in the picture directly. The «Harry Potter Universe», «Aliens Universe», «The Middle Earth Universe» are popular universes. Among comic books, now competing with each other and constantly expanding, there are two movie universes - Marvel and DC.

"The comic book universe is adventurous, mystifying, and filled with heroes, villains, and cosplaying Comic-Con attendees» [9]. The Marvel
Universe started in 2008 with «Iron Man» with Robert Downey Jr. For several years, Marvel Studios did not have the funds to distribute their films, and they made a deal with two companies - Universal Pictures and Paramount Pictures, according to which these companies took over the distribution of the film (marketing, PR, and so on). When Disney acquired Marvel Entertainment in 2009, Marvel Studios became a part of Walt Disney Pictures, and the company had the opportunity to distribute its films. Walt Disney Pictures even had to buy out the remaining rights from Paramount Pictures to get full control over the production and distribution of Marvel Studios. It is also important to mention the numerous TV series that are formally inscribed in the movie-project - the projects of ABC, Netflix, Hulu and other channels. The Marvel Universe began in 2008 with Iron Man, and in 2018 the film «Avengers: The Infinity War» is released - it sums up everything that the studio has been doing for ten years. Ten years have passed within the films themselves. Similar cases have already occurred in the movies. For example, in the Harry Potter franchise actors who performed the role of magicians from the very first films changed with the fans.

But the movie universe goes further. Remember the beginning of the «Avengers: Age of Ultron», where a team of heroes fought with Hydra? Most of this battle was left behind. Remember Bruce Banner in Ragnarok, who was horrified at the thought that he spent several years in the image of the Hulk. And after all, the audience also has not seen the character since his appearance in the «Avengers: Age of Ultron». We learn what happened to the Hulk, from his narration. This is a very unusual approach. It means that the universe lives even when the audience does not see it. We see how the characters grow old, change and develop. The cinema had not yet seen anything of such a high level.

The newest DC universe and media franchise, based on the comics of the publishing house DC Comics and developed by the film company Warner Bros. Pictures, was launched in 2013 by Zach Snyder's «Man of Steel», in which Henry Cavill played the role of Superman. At the moment, five movies have already been released in the framework of this film series. Warner Bros. Pictures plans to shoot twelve more films of the series with a mix of the plot, but with different characters that will sometimes interact with each other.

A superhero is a phenomenon common to the American comic book and is widely regarded as an integral part of the genre. The classical understanding of a super hero is a fictional character endowed with extraordinary physical abilities («super powers»), which he directs to accomplish feats for the common good [10]. After the debut of a prototypical superhero named Superman in 1938, the idea of a superhero - from short, episodic adventure stories to perennial and multi-series sagas - became dominant for American comics, from which it subsequently spread to other media. Superman, similar to the hero of myths, based on characters such as Samson and Hercules, would change the world in the days of his creators Siegel and Schuster and fight for justice. 1938 - the world is on the edge of the Second World War. The appearance of a superman standing 
guard for good and justice and capable of resisting any threat could not pass unnoticed. In the universe of comics, the first type of superheroes appeared - a hero with superhuman abilities. As a rule, these heroes have an extraterrestrial origin, for instance, Superman, the god of thunder Thor or Aquaman.

The comics boom began with the appearance of Spider-Man in August 1962. The character was created by Stan Lee and painted by Steve Ditko. Comics about Spider-Man produced a real explosion of reader interest [10]. From this moment, active introduction of the comics as a popular genre into American culture began. The wave of reader interest produced various thematic clubs, fan clubs and comic book festivals. Rare old issues of graphic stories were sold at auctions for fabulous sums. The end of the 80's was marked by the beginning of a new boom - screenings of comic books. In 1989, on the fiftieth anniversary of Batman a film of the same name was released. Next, a whole series of movies taken from graphic histories began.

Batman appeared in contrast to Superman, and in the competing universe of Iron Man. This is a different kind of superhero; the hero in the mask. They do not have super abilities or extraterrestrial origin, but they have an outstanding intellect. The appearance of this kind of hero is an appeal to society to act. The image of the hero seems to say that in order to do the best, one does not need superpowers, but must simply follow the principles of freedom and justice.

There is a whole galaxy of superheroes that have become so unconsciously as a result of an accident or experiment. They include Spider-Man, Hulk, the Fantastic Four, Doctor Manhattan, Deadpool, etc. Each of them, having received new abilities, passes through a turning point and decides to serve either good or evil.

When uttering the word «superhero», the first associations are Superman, Batman, Spiderman, Iron Man, Captain America, etc. Anyway, from the first screen versions to the present, the superhero world was predominantly male. Women roles occupied the second plan and boiled down to the image of the superhero's girlfriend in trouble. A huge number of superheroes on the pages of comic books had no place in the movieuniverse until recently. Cinematography is a reflection of social processes, and, therefore, very sensitive to changes in societies mood. In the modern world, gender equality issues are extremely acute. In addition, among some of the movements gaining momentum, it is no longer simply about equality, but about the superiority of women over men. A woman comes to the fore, she wants to be visible, wants to build a career, be successful, and supervise. Cinematography immediately reacted to such sentiments by the fact that they began to introduce female characters into so-called crossovers, and later even releasing solo films about superheroines. Bright examples can serve as the Black Widow, Scarlet Witch, Captain Marvel, Wonder Woman and even anti-heroine Harley Queen, etc. It should be noted that in the pages of comics there are many female images, many of which, judging by social attitudes, will get the opportunity to get in the limelight. This happened already in a period of rising tolerance, as a result of which the number of dark- skinned characters (Warrior, Black Panther) and characters with reduced physical abilities (for example, Daredevil) increased in the films. It seems that the guardians of the Galaxy, Gomorrah, Nebula and the whole inflorescence of extraterrestrial beings can also be considered as promotion of the equality of peoples and tolerance to the representatives of another race.

\section{Conclusion}

Thus, the primary analysis showed that the movieuniverse created by American comic books, shows steady growth and is gaining increasing popularity, which is confirmed by the unprecedented gross box office from the rental of films about superheroes. As for the very image of the superhero, under the influence of socio-cultural processes, he underwent significant changes and departed from the classical Superman, gaining a variety of options. It should be noted that the comics and their screen versions are of interest for further study both in linguistics (in connection with the emerging need to create a dictionary of the superhero universe (timeline, movie universe, crossover, etc.)), and from a socio-cultural perspective. Through comics, an introduction into the mass consciousness of the most basic and newest values of culture is carried out. For example, it is interesting that along with positive characters, so-called antiheroes (Harley Quinn, Joker, Venom, etc.) are also gaining unprecedented popularity, and the reasons for this phenomenon can become the object of further research.

\section{References}

1. G. Kovacs, C.W. Marshall, Classics and Comics (Oxford University Press, 2011)

2. A. Volkov, K. Kutuzov, The secret history of comics (AST, Moscow, 2017)

3. W. Eisner, Theory of Comics \& Sequential Art (Poorhouse Press, 1985)

4. Ye. Kozlov, The communication of the comics (in the textual and semiotic aspects) (Volgograd, 1999)

5. Ye. Anisimova, The linguistics of a text and intercultural communication (based on Creole texts) (Academia, Moscow, 2003)

6. K. Kukkonen, Contemporary Comics Storytelling (University of Nebraska Press, 2013)

7. M. Hannah, Comics and Language: Reimagining Critical Discourse on the Form (University Press of Mississippi, 2013)

8. S. Mario, The Language of Comics (Intertext) (London: Routledge, 2004)

9. L. Tim, Super Graphic: A Visual Guide to the Comic Book Universe (Chronicle Book, 2013)

10. S. Beatty, The DC Comics Encyclopedia, Updated and Expanded (DK Publishing, 2008) 